УДК 004.912

Oksana Khomik

http://orcid.org. 0000-0001-9094-5005

$\mathrm{PhD}$ in Pedagogy, Associate Professor of the Department of Finance and Credit

Academy of Recreational Technologies and Law Lutsk, Ukraine

Okshom@ukr.net

Oksana Kovalchuk

http://orcid.org.0000-0001-5371-9543

$\mathrm{PhD}$ in Pedagogy, Associate Professor of the Department of Higher School Pedagogics Academy of Recreational Technologies and Law Lutsk, Ukraine kasana17@ukr.net

\title{
PRACTICAL COURSE-CONFERENCE USING YOUTUBE AS INTERACTIVE TEACHING FORM OF PROFESSIONALS IN HIGHER EDUCATIONAL INSTITUTIONS
}

The system of views on the problem of using interactive teaching methods in higher educational institutions has been considered in the article. The content of the concept "interactive teaching methods" has been revealed. The significance of practical course as the form of organization of educational interaction between the teacher and the students has been characterized. The role of the teacher and the students has been determined during practical courses-conferences. The procedure of conducting of interactive practical course-conference using YouTube has been described. The given examples of video materials, collected from YouTube for conducting practical course-conference on the theme "Language Etiquette" from the discipline "Management" have been given. The results of questioning of higher educational institutions' teachers due to the conducting of their interactive practical course-conferences using YouTube have been introduced.

Key words: interactive methods; practical course-conference; specialists; teachers; YouTube.

(C) Ковальчук Оксана, Хомік Оксана 2017

\section{Introduction}

The state educational standards of Ukraine are directed at the students' formation of knowledge and skills that will allow graduating students to be competitive and employed in the labor market. The formation of the specialist's ability to rebuild the system of their 
own professional activity becomes dominating under these conditions taking into account socially-significant goals and regulatory restrictions. If the main goal of high educational system is training of such a specialist, the teaching process should be organized in such a way as to provide the all-round development of the individuality. However, up-to-date situation requires changes in strategy and tactics in the university studies due to the future specialists' training.

The main task of higher educational institution is training of flexible, non-standard specialists that are able to follow the world changes in time. In this connection in students' training for professional activity the innovational methods of organization of educational process should be used. In the process of teaching it is necessary to pay attention first of all, to those methods in which students identify themselves with the educational material, are included in the investigated situation, which induces them to active actions. They are in a state of success and, accordingly, motivate their educational behavior. Interactive teaching methods meet the most consistent requirements.

Today the great amounts of theoretical and experimental works of domestic and foreign teachers are devoted to the problems of using innovating teaching methods in higher educational institutions. A. Aleksyuk, I. Dobroskok, V. Kotsura, V. Kremen, S. Nikitchyna, V. Ilyina, S. Proleyeva, M. Lysenko, P. Saukh and others studied the general-theoretical, scientific-practical problems of the innovative paradigm in high school, some progressive forms and technologies of teaching, experience and prospects of their use in educational practice.

The understanding of the new in the educational process with useful, progressive, positive, modern is studied by such researches of pedagogical innovations as O. Abdolova, O. Isakov, V. Lukyanenko, O. Vasilenko, I. Galitsa and O. Galitsa, V. Dokuchaev, O. Fatkhutdinova and others.

The following scientists, such as M. Clarin, V. Kremen, L. Pyrozhenko, E. Polat, G. Pyatakov, A. Khutorsky and others, paid attention to the development and the use of interactive forms of teaching in the process of future specialists' training.

The issue of conducting interactive practical course-conferences using YouTube in educational process of higher educational institutions is still underdeveloped, which 
determines the topicality of our research, nevertheless the presence of a large number of scientific works devoted to the problem of using interactive teaching methods. The aim of this article is to develop the structure of the conducting and scientific substantiation of the efficiency of the use of interactive practical course-conferences using YouTube.

\section{Methods}

One of the key tasks of higher school in the informational society among top-priority problems is the training of high-class specialist for his professional activity under the conditions of the development of modern informational technologies. Nowadays it is impossible to imagine the educational process in higher school without the use of information technologies and teaching means. They made possible to access a huge amount of different types of information for every specialist. But to change the access of information and computer resources into their possession, students must acquire the knowledge and skills that would become the guarantor of the full implementation of personality's skills and professional qualities of future specialist's training for vital activity in an open information society.

In the opinion of V. Lukianenko, information and communication technologies are integrated into the educational process for the organization of students' independent educational activity in non-auditing conditions (Lukianenko, 2014, p.71).

The teachers of higher educational institutions have the task to help the student - the future specialist to master the skills of future professional activity successfully, to form the appropriate type of professional thinking, to reveal ways of further improvement of his competence.

The constant professional growth of a modern specialist in the society, the introduction of innovations, and the professional dynamics - that is the graduate of higher educational institution should be prepares for. The collaboration of teachers and students in the educational process is intended to facilitate the formation of an initiative, independent, creative person with a clear active life position.

Modern pedagogical reality demonstrates the tendency to transition to a new creative stage, when the dominant humanistic education paradigm stimulates teachers to find new forms of interaction with students, with the advantage of dialogue, which is characterized 
by improvisation, co-creation, interaction, which is ensured by the use of interactive forms of study at higher school.

The term «interactive» comes from the English word «interact». In this case, the term «interactive teaching» is understood differently. Many experts interpret this concept as the teaching using information and computer technologies. Since the very idea of such training arose in the mid of 1990s with the advent of the first web browser and the beginning of the Internet development.

According to Svitlana Sysoeva's opinion, «intractive learning» characterizes such educational process, which is built on the basis student's interaction with teaching surrounding and educational environment; is grounded on the psychology of human relationship and interaction; the essence of which lies in the organization of common process of cognition, when the knowledge is gained in common activity through the dialogue, the polilogue of the students and the teacher (Sysoeva, 2011, p. 6).

According to T. Koval, interactive teaching foresees, first of all dialogue teaching, in the process of which the interactions between subjects of the educational process are carried out. It can be organized using interactive teaching technologies. The essence of interactive teaching lies in that, the educational process takes place under conditions of constant, active interaction of all subjects of teaching (teachers and students). This is mutual teaching (collective, group, study in cooperation), where the student and teacher are equal, equivalent subjects of the study (Koval, 2011, p. 4).

I. Kurysheva considers the interactive methods of teaching as «the ways of organizing active, productive interaction of students with the teacher, with different sources of information, as well as with a computer in the form of educational, business, role-playing games, discussions, implementation of projects, analysis of specific situations, in which the development of new experience and obtaining new knowledge, an opportunity for self-realization of students» (Kurysheva, 2010, p. 12).

We support the opinion of O. Siroshtan, who defines the methods of interactive teaching as "a system of methods for the purposeful interpersonal interaction of teachers and students, aimed to solve the educational and training tasks of future teachers' 
professional training in the process of educational and cognitive activity of higher educational institution" (Siroshman, 2012, p. 88).

We distinguish the following four levels of organizational forms of teaching in the higher educational institutions according to the method of organization of interactive teaching: the first level covers the forms of organization of educational process or innovation at a distance (distance form of learning), or traditionally (classroom and nonclassroom forms of teaching); the second level relates to the organization of the system of education (individual, individual-group, group forms of teaching, etc.); the third level covers the organization of educational course in the form of interactive lectures, seminars, practical and laboratory works, excursions, credits, colloquiums, exams; the fourth level refers to the forms of organization of students' work in the educational and communicative situation of a partial, limited or complete autonomy.

Interactive forms of teaching V. Istomina understands as forms of organization of the educational process, which assist to the diverse study of educational issues, the active interaction of students and teachers, the active exchange of thoughts between them, aimed at the formation of professional skills, the education of professionally significant personal qualities of the future specialist, for the developing of correct understanding of the content of the topic under study and ways of its practical use (Istomina, 2013, p. 175).

The high class professionalism of the teacher during the organization of the educational process manifests itself in the transformation of a socially significant into personally significant, that is, in the purposeful induction of future specialists to their active work on themselves. In this case, the creative component of the teacher's activity is dominant, which means that interactive teaching methods, which stimulate the systematic and purposeful work of the students themselves, become important in classroom courses. The independent cognitive activity is of great importance, the specific feature of which, according to students' thoughts, is the lack of teacher assistance in the mastering of educational material. Such an opinion cannot be true and productive, since in this case it is the pedagogical management that generates educational cooperation. The teacher does not take part in the task accomplishment, but he organizes the training activity, creates the necessary conditions and mood. The practical courses are based on the intensive 
independent work of students, which are a flexible form of organization of educational interaction.

One of the types of practical courses that assist the effectiveness of comprehension of learning information and the growth of independent and purposeful cognitive activity of students is a practical course-conference using YouTube, which gives the opportunity to form these characteristics for many academic disciplines in the process of studying at a high school. Appointment of a practical course-conference using YouTube is to teach students to participate in scientific conferences, to create a scientific environment that is the closest to research activity. During the implementation of such a form of organization of educational interaction students not only realize their achievements, but also understand the necessity for their analysis and logical conception. Thus, the most important result of a practical course becomes the student's understanding of his potential and the possibilities of its use. It is well-known that the integral part of educational process is the reflection separation as the final stage of the course, and in this form it is not only implemented on a particular concrete stage, but directly penetrates the entire course of interaction.

The practical course-conference using YouTube is conducted according to the scheme of usual conferences and consists of a system of reports on each of the issues that cover the defined topic of practical course in advance. Each speech is a logically completed report prepared within the framework of the program and the totality of students' speeches comprehensively highlights the topic of the course. The video materials collected from YouTube are used as a basis for the report.

The peculiarity of interaction with students foresees the preparatory work, which begins beforehand. The teacher acquaints students with the task, content and with the peculiarities of the organization of work before and during the course-conference which is very important. The subject and the questions are informed beforehand that reveal it.

While preparing for a practical course, students select videos from YouTube independently, which, in their opinion, are the most suitable to reveal its topic.

At the practical course the «leading student» announces the theme, presents the speakers, gives them a word. The speaker introduces his videos to the audience. After the video is completed, the discussion begins. In practical course, speakers should to 
demonstrate the ability to interact with the audience, to stimulate the thinking of the audience through problem-setting questions, to keep listeners' attention and ability to get out of problematic situations. The speaker's skill is manifested in the correctness of the selection of video materials, the argumentation, in the explanation of the presented material, the ability to formulate conclusions.

A practical course-conference using YouTube as an interactive form of organization the students' educational work actualize the ability to select correctly the materials and the ability to interact with a group of people who need to provide the information.

Students' work on a course-conference using YouTube is evaluated according to the following criteria:

$\checkmark \quad$ the content of the video materials: the correspondence to the subject, the simplicity of the material;

$\checkmark \quad$ the achievement of the goals of the report: the correspondence of the content of the video material with the stated goals and the perception of this material by the listeners;

the interaction with the audience: the managing of the audience's attention, including answers to the questions, relevant jokes, rhetorical questions.

During the practical course-conference, the listeners evaluate each speech on the questionnaires, which serve as the basis for calculating the average score. The presence of the recommendations of the listeners in these questionnaires will allow improving the speaker himself.

Analyzing the results the teacher pays special attention to the discussion of the common experience gained at the conference, the difficulties encountered in the class, the clarification of the causes of the observed behavioral acts, the definition of the most productive positions.

For the preparation and conducting of this type of practical course, some efforts are required from the teacher. A special attention should be paid to forecasting of possible difficulties, among which one can distinguish: different level of preparedness of students, which potentially blocks the manifestation of activity during the formulation and discussion of questions; insufficient volume of materials on the topic; the passivity of 
participants; insufficiently formed skills to represent the prepared material; the emergence of emotional stress during discussions; difficulties in managing the group; the emergence of interpersonal conflicts among participants. It is also necessary to predict the multi-role position of the teacher during the whole lesson: a manager, a consultant, an assistant, a participant, an expert.

For example, for conducting a practical course-conference on the theme «Language Etiquette» from the discipline «Management», students can use the following video materials for the presentation (Figure 1-2).

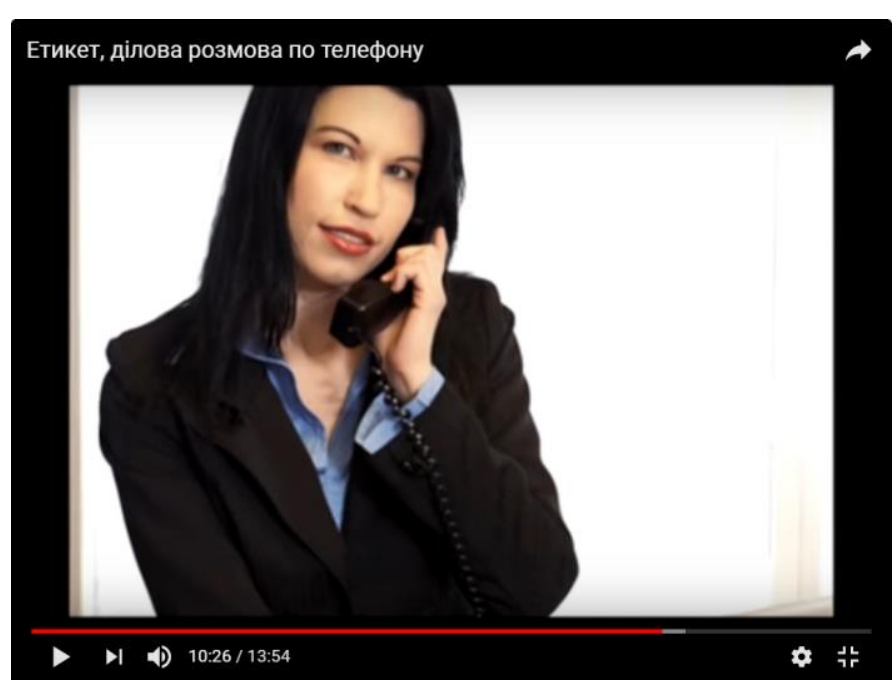

Fig. 1. YouTube video on the theme "Etiquette, business phone conversation"

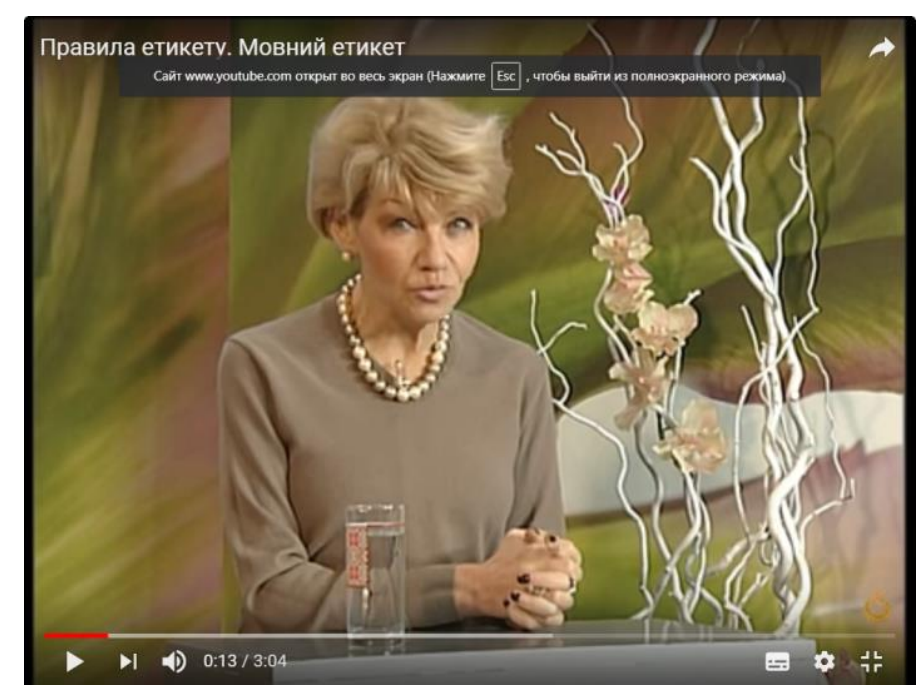

Fig. 2. YouTube video on the theme "Etiquette rules, language etiquette" 


\section{Results and Discussion}

We conducted a questionnaire among 48 teachers from Eastern European National University named after Lesia Ukrainka and the Academy of Recreational Technologies and Law of the economic specialties to find out if the teachers use practical courseconference using YouTube application in their practice. The results showed that only two of the respondents, that is, $4.2 \%$, conducted a practical course in such a form, $42.7 \%$ did not conduct practical course-conference using YouTube, 54.1\% of teachers partly used video materials from YouTube while conducting practical course (Fig. 3).

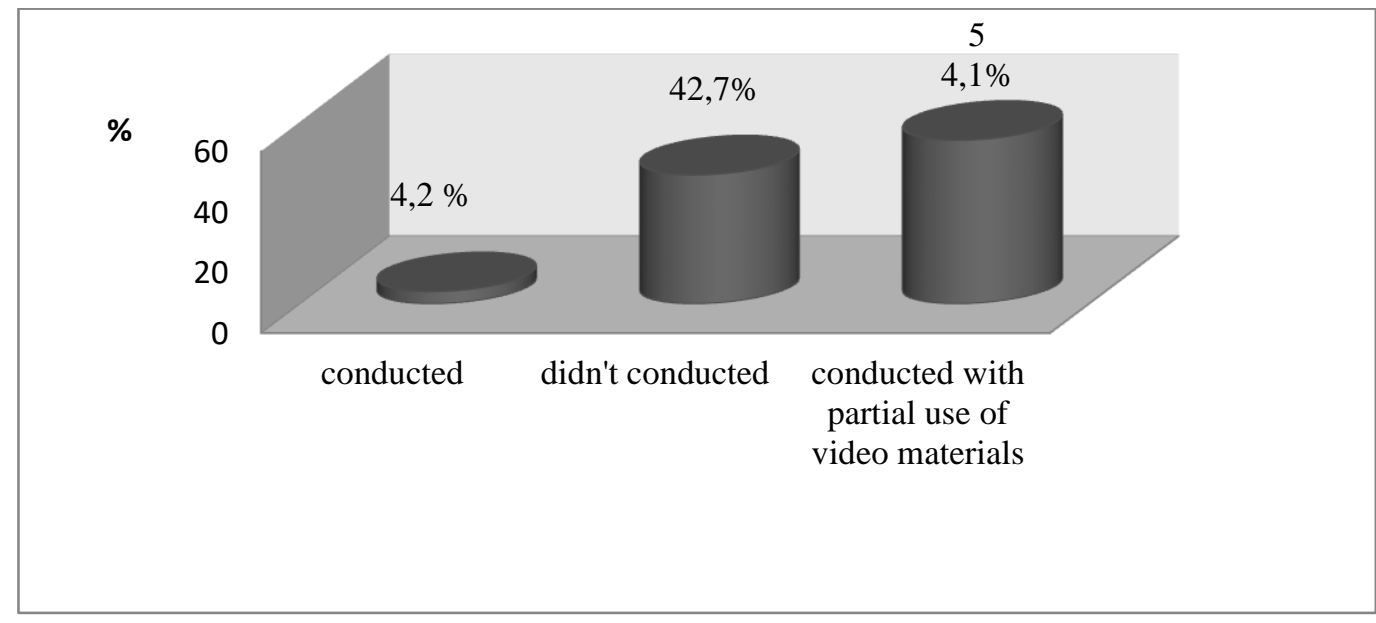

Fig. 3. The distribution of teachers' responses due to their conducting of interactive practical course-conferences using YouTube $(\%)$

Characterizing the teachers' responses whether they would like to implement such a lesson after having studied the structure of a practical course-conference using YouTube, it can be confirmed that $93.8 \%$ of the polled teachers answered «yes, they would like to», $4.1 \%$ of respondents answered «no, they would not like» and only $2.1 \%$ of the teachers had difficulty to answer the question (Fig. 4) 


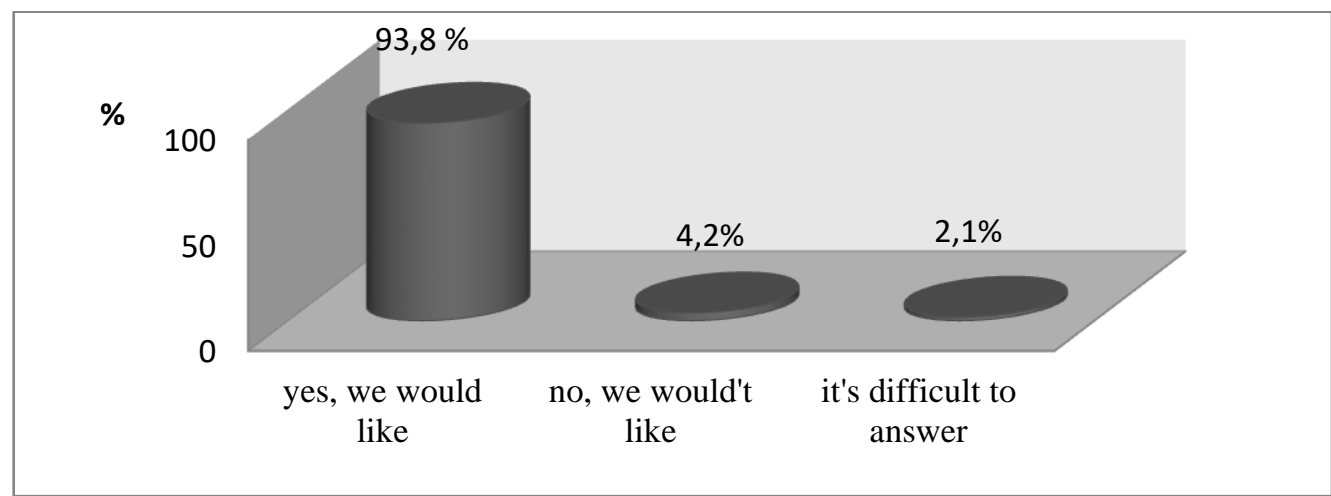

Fig. 4. The distribution of teachers' responses due to the desire of conducting a practical course-conference using YouTube on the described structure.(\%)

Thus, the results of the conducted questionnaire give the grounds to conclude that conducting a practical course in the form of an interactive practical course-conference using YouTube is interesting and perspective.

\section{Conclusions}

1. The use of interactive methods during teaching subjects in a higher school has a positive effect on the educational process and enhances students' motivation to work.

2. The conducting of a practical course-conferences using YouTube provides the disclosure of the content of the topic on specific professional examples that promote the formation of students creative approach, involve them in collective cognitive activity, discussions, etc.

3. The proposed structure of conducting a practical course-conferences using YouTube in the educational process of the university expands the possibilities of traditional education, improves the methodology of teaching disciplines in the new conditions.

4. The analysis of the questionnaires of higher education teachers showed that practical course-conferences using YouTube don't conduct, but they are interesting for teachers.

5. Prospects for further research will be the development of methodological recommendations for teachers of higher educational institutions to conduct practical course-conference using YouTube. 


\section{References:}

Istomyna, V. (2013). Vliyaniye aktivnykh form obucheniya na vospitaniye professyonalno znachymykh kachestv lychnosty budushchikh bakalavrov professionalnoho obucheniya $v$ vuze [The influence of active educational forms on the education of professionally significant personal qualities of future bachelors of vocational training in the university]. Vestnik ChHAA, 63, 172-181.(rus)

Koval, T.I. (2011). Interaktyvni tekhnolohii navchannia inozemnykh mov u vyshchykh zakladakh osvity [Interactive technologies for teaching foreign languages in higher education institutions]. Informatsiini tekhnolohii $i$ zasoby navchannya: elektrone naukove fakhove vydannya "Instytut informatsiinykh tekhnolohii $i$ zasobiv navchannia NAPN Ukrainy", Kyiv, 6 (26). https://journal.iitta.gov.ua/index.php/itlt/article/view/546/451 (ukr)

Kurysheva, I. (2010). Interaktyvnye metody obucheniia kak faktor samorealizatsii starsheklassnykov v uchebnoi deyatelnosty pri izuchenii estestvennonauchnykh dystsyplin [Interactive methods of teaching as a factor in the self-realization of high school students in learning activity in the study of natural science disciplines]. Avtoreferat dys. ... kandydata pedahohycheskykh nauk: 13.00.01, Nyzhnyi Novhorod, 20.(rus)

Lukianenko, V.V. (2014). Dosvid uprovadzhennya dystantsiinoho navchannia dlia orhanizatsii samostiinoi roboty studentiv $\mathrm{z}$ anhliiskoi movy [Introducing distance learning experience for organizing students' independent work in English]. Pedahohichnyi protses: teoriya i praktyka. 2, 70-75. http://nbuv.gov.ua/UJRN/pptp_2014_2_17 (ukr)

Sysoieva, S. O. (2011). Interaktyvne navchannya doroslykh u systemi pisliadyplomnoi pedahohichnoi osvity [Interactive adult education in the postgraduate pedagogical education system]. Naukovi pratsi Chornomorskoho derzhavnoho universytetu imeni Petra Mohyly kompleksu "Kyievo-Mohylianska akademiia". Ser. : Pedahohika. 158 (146), 5-10. (ukr)

Siroshtan, O. (2012). Interaktyvni metody navchannia v protsesi profesiinoi pidhotovky maibutnikh sotsialnykh pratsivnykiv [Interactive teaching methods in the process of training future social workers]. Sotsialna pedahohika: teoriia ta praktyka. 1, 85-90.(ukr)

\section{Література:}

Истомина В. В. Влияние активных форм обучения на воспитание профессионально значимых качеств личности будущих бакалавров профессионального обучения в вузе. Вестник ЧГАА. 2013. Т. 63. С. 172-181.

Коваль Т. І. Інтерактивні технології навчання іноземних мов у вищих закладах освіти. Інформаційні технології $і$ засоби навчання: електрон. наук. фах. вид. 2011. - № 6 (26). - Режим доступу: https://journal.iitta.gov.ua/index.php/itlt/article/view/546/451.

Курышева И. В. Интерактивные методы обучения как фактор самореализации старшеклассников в учебной деятельности при изучении 
естественнонаучных дисциплин : автореф. дис. ... канд. пед. наук: 13.00.01 «Общая педагогіка история педагогики и образования». Нижний Новгород, 2010. 20 c.

Лук'яненко В.В. Досвід упровадження дистанційного навчання для організації самостійної роботи студентів 3 англійської мови. Педагогічний процес:теорія $i$ практика. 2014. Вип. 2. С. 70-75. - Режим доступу: http://nbuv.gov.ua/UJRN/pptp_2014_2_17.

Сисоєва С. О. Інтерактивне навчання дорослих у системі післядипломної педагогічної освіти. Наукові праці [Чорноморського державного університету імені Петра Могили комплексу "Києво-Могилянська академія”]. Сер. : Педагогіка. 2011. Т. 158. Вип. 146. С. 5-10.

Сіроштан О. В. Інтерактивні методи навчання в процесі професійної підготовки майбутніх соціальних працівників. Соціальна педагогіка: теорія та практика. 2012. № 1. С. 85-90.

\title{
ПРАКТИЧНЕ ЗАНЯТТЯ-КОНФЕРЕНЦІЯ 3 ВИКОРИСТАННЯМ YОUТUВЕ ЯК ІНТЕРАКТИВНА ФОРМА НАВЧАННЯ ФАХІВЦІВ У ВИЩИХ ЗАКЛАДАХ ОСВІТИ
}

\author{
Оксана Хомік кандидат педагогічних наук, доцент кафедри фінансів і кредиту, \\ ПВНЗ «Академія рекреаційних технологій і права», м. Луиьк, Україна \\ Okshom@ukr.net
}

\begin{abstract}
Оксана Ковальчук кандидат педагогічних наук, доцент кафедри педагогіки вищої школи, ПВНЗ «Академія рекреачійних технологій і права», м. Луцьк, Україна kasana17@ukr.net
\end{abstract}

У статті розглянуто систему поглядів на проблему використання інтерактивних методів навчання у вищих закладах освіти. Розкрито зміст поняття «інтерактивні методи навчання», під якими розуміється взаємопов'язана спільна діяльність студентів і викладача, за якої всі учасники освітнього процесу взасмодіють один з одним, обмінюються інформацією, спільно вирімують проблеми, моделюють ситуації, занурюються в атмосферу співпраці зі спільного вирішення проблем. Доведено, щзо використання інтерактивних методів під час викладання навчальних дисциплін у вищій иколі позитивно впливає на процес навчання та підвищує у студентів мотивачію до роботи. Охарактеризовано значення практичних занять як форми організації навчального взаємодіі між викладачем та студентами. Визначено роль викладача та студентів під час проведення практичних занять-конференцій. Описано процедуру проведення інтерактивного практичного заняття-конферениії з використанням ҮоиТиве, яка розиирює можливості традиційного навчання, удосконалює методику викладання дисциилін в нових умовах. Доведено, щзо проведення практичних занять у формі конференції з використанням Үоитиве забезпечує розкриття змісту теми на конкретних професійних прикладах, які сприяють формуванню у студентів 
творчого підходу, залучають їх до колективної пізнавальної діяльності, дискусій тощуо. Наведені приклади відеоматеріалів, зібраних з ҮоиТиье для проведення практичного заняття-конференції на тему «Мовний етикет» $з$ навчальної дисцииліни «Менеджмент». Представлені результати анкетування викладачів вищих навчальних закладів щуодо проведення ними інтерактивних практичних занять-конференцій з використанням ҮоиТиье, які засвідчили про те, щуо практичні заняття у наведеній формі є малопоширеними у вищих закладах освіти, але $\epsilon$ цікавими для викладачів.

Ключові слова: викладачі; інтерактивні методи; практичне заняттяконференція; фахівиі; ҮоиТиbе.

\section{ПРАКТИЧЕСКОЕ ЗАНЯТИЕ-КОНФЕРЕНЦИЯ С ИСПОЛЬЗОВАНИЕМ YOUTUВЕ КАК ИНТЕРАКТИВНАЯ ФОРМА ОБУЧЕНИЯ СПЕЦИАЛИСТОВ В ВЫСШИХ УЧЕБНЫХ ЗАВЕДЕНИЯХ}

Оксана Хомик кандидат педагогических наук, доцент кафедры финансов и кредита, ЧВУЗ «Академия рекреационных технологий и права», г. Луцк, Украина

Okshom@ukr.net

Оксана Ковальчук кандидат педагогических наук, доцент кафедры педагогики высшей школы, ЧВУЗ «Академия рекреационных технологий и права», г. Луцк, Украина kasana17@ukr.net

В статье рассмотрена система взглядов на проблему использования интерактивных методов обучения в высших учебных заведениях. Раскрыто содержание понятия «интерактивные методы обучения». Охарактеризованы значение практических занятий как формы организации учебного взаимодействия между преподавателем и студентами. Определена роль преподавателя $u$ студентов во время проведения практических занятий-конферениий. Описана прочедура проведения интерактивного практического занятия-конференции с использованием ҮоиТиье. Приведенные примеры видеоматериалов, собранных с YоuТube для проведения практического занятия-конференции на тему «Речевой этикет» по дисииплине «Менеджмент». Представлень результать анкетирования преподавателей высших учебных заведений по проведению ими интерактивных практических занятий-конферениий с использованием Үоитиье.

Ключевые слова: интерактивные методы; практическое занятиеконференция; преподаватели; специалисть; ҮоиТиье. 